\title{
Leadership Attributes Good vs. Bad- Lessons from Vidur Neeti (Mahabharata)
}

\author{
Anamika Patel \\ School of Management Studies, Varanasi, 221001, India \\ anamikapate124@gmail.com
}

\section{ARTICLE INFO}

Article history

Received 7 January 2020

Revised 15 February 2020

Accepted 20 April 2020

Keywords

Vidur Neeti

Leadership

Mahabharata

Good and Bad Leader

Management

\section{ABSTRACT}

The vast ocean of Indian Santana scriptures contains a lot more gems of wisdom for the modern era than they are accounted for. One such deep sea of knowledge is Vidur Neeti, given in Mahabharata). Vidur Neeti, mentioned in the third chapter of Udyog Parva of Mahabharata, contains the age-old wisdom which offers new insights every time anyone explores the depths of its pages. Prajaagara Parva- a subsection of Udyog Parva, includes a dialogue between King Dhritarashtra, and Prime-minister Vidur wherein Vidur advises the king about the proper code of conduct. The paper lists those verses which describe wise and foolish qualities, which can be attributed to a good and bad leader, respectively.

This is an open access article under the CC-BY-SA license

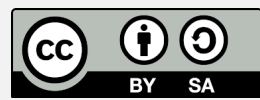

\section{Introduction}

The great epic Mahabharata consists of so many universal aspects of human behavior and knowledge that it has been said by the creator and author of the great epic- Maharshi Krishna Dwaipayana Vyas that यदिहास्ति तदन्यत्र यन्नेहास्ति न तत्क्वचित् What is here is elsewhere; what is not here is nowhere (Mahabharata; Swargarohan Parva 5.50). Vidur Neeti is given in the third chapter of Udyog Parva of Mahabharata and contains ethical and tactical insights of the human behavior which are to be implemented in principles.

A devotee of Shree Krishna, Vidur was the wise prime minister of Kuru-vansh. After Shree Krishna he was the most revered advisor for pandavas. Half-brother of Dhritarashtra and Pandu, Vidura was believed to be an incarnation of Dharmaraj (Yamaraj) according to some accounts. As Dharmaraja is considered to be knower of all dharma (duties and codes of conduct), Vidur was considered an expert in the laws of Dharma. Kuru Naresh Dhritarashtra has entitled Shree Vidur with adjectives as "Mahapraagyam" - the one with highest intellect, "Deerghadarshinah" farsighted visionary (Prajaagara Parva 1.5), "Dharmaarthkushalah" - proficient in dharma and finances/charity (Prajaagara Parva 1.15), "Mahabuddhe" - of great wisdom (Prajaagara Parva 3.1) and "Mahamate" - of great wit and intelligence (Prajaagara Parva 4.50).

The paper contains the qualities of good and bad leaders as stated by Mahatma Vidur in Prajaagara Parva- a subsection of Udyog Parva of Mahabharata, under the context of qualities of wise and fool persons; panditah and mudhah [1].

\section{Method}

This paper takes up a literary study approach by abstracting various interpretations of Vidur Neeti. Shenoy [2] has identified the principles as stated in Vidur Neeti on how to be an ideal manager and administrator. He has integrated the management principles as given by Henry Fayol 
and Peter Drucker with the principles stated in Vidur Neeti, and tried to show the added elementary principles missing in their stated principles.

Khandelwal [3] takes up a holistic approach and does an analysis of Vidur Niti from managerial point of view and covers areas as qualities of wise and fool persons, ethical decisionmaking, words of wisdom, development of leadership qualities, stress and family management and other management topics.

A study of Vidur Neeti in special reference to Indian ethics has been done by Mahajan [4] where she has tried to explore the utility of Vidur Neeti in various aspects of life. From politics to normal day to day life, the ways of life as told by Vidur have been touched upon by her.

Guruprasad and Rath [5] have introspected upon the spiritual traits of a leader as stated in Vidur Neeti, compared Shree Vidur and Dhritarashtra and provided reflections thereby on the contributing characteristics of a leader in modern era [6].

\section{Results and Discussion}

This section discusses good leadership attributes taken from the reading and interpretation of Vidur Neeti. There are nine good leadership attributes, and 7 bad leadership attributes identified.

\subsection{Knowledge of self: Productive with discretion, and Ethical}

ātma-jūānam samarambhas titikṣā dharma nityay $\bar{a} \mid$ yam arthān nāpakarșanti sa vai paṇ̣̂ita ucyate || Prajaagara Parva 1.17 || [1]

Here, with this shlok it can be inferred that a wise leader is one who has knowledge about his/her own qualities and capacity, is productive and doesn't exert himself/herself beyond the limits, shows forbearance means doesn't get affected by profit or loss and is ethical in dealings.

\subsubsection{Discretion with business secrets}

yasya krtyaì na jānanti mantram vā mantritam pare |

kṛtam evāsya jānanti sa vai paṇ̦ita ucyate || Prajaagara Parva 1.20 || [1]

Here, Mahatma Vidur talks about the wisdom of secrecy of intended projects and acts from enemies and says that the acts should be made public only after they have been finished. Thus, it demonstrates the leadership quality of being discreet with secrets of the business and never to disclose confidential information to anyone.

\subsubsection{Ethical in profit-making}

yasya samisārin̄i prajūā dharmārthāv anuvartate |

kāmād artham vrnịte yah sa vai paṇdita ucyate|| Prajaagara Parva 1.21 || [1]

Profit-making is considered as one of the foremost criterion of any business. This verse of Vidur Neeti talks about a wise leader of giving as much weightage to virtue and ethics as profits. A wise leader is one who chooses ethical conduct over material gains every time.

\subsection{Intrinsically motivated, and Observant}

yathā śakti cikīrșanti yathā śakti ca kurvate |

na kiñcid avamanyante paṇditā bharatarșabha|| Prajaagara Parva 1.22 || [1] 
A wise leader is one who is intrinsically motivated to exert efforts to the best of his/her ability and act accordingly. They observe and pay attention to minute details and do not disregard any thing as irrelevant or insignificant.

\title{
3.3. Quick grasping power Listening ability, and Non-indulgent in useless gossip
}

\author{
kṣipram vijānāti ciraṁ șrnoti vijñãya cārtham bhajate na kāmāt | \\ nāsamprș̣to vyupa yunkkte parārthe tat prajñānam prathamam paṇditasya $\|$ \\ ||Prajaagara Parva 1.23 || [1]
}

This verse mainly starts telling about the social behavioral qualities of a good leader. Ability to grasp complex subjects quickly is the first one mentioned in the verse; it may be linked to understanding the complexities of human psychology. Other qualities of a wise leader Mahatma Vidur talks about are: patient listening skills, pursuit of goals with careful judgment and not with selfish desires and non-indulgence in gossiping and discussing other people's business without being asked.

\subsection{Setting of attainable goals Emotional intelligence Perseverance}

nāprāpyamabhivāñancanti naștam necchanti śocitum |

āpatsu ca na muhyanti narāḥ paṇdita buddhayaḥ|| Prajaagara Parva 1.24 || [1]

In this verse, Shree Vidur talks about the quality of a leader to not set unattainable impossible goals for self or others. A good leader shows emotional intelligence in the face of loss and do not waste the time in grieving over losses. He/she is perseverant, always stays firm and does not lose heart amidst any calamity or difficulty.

\subsection{Planning in advance: Time management}

niścitya yah prakramate nāntar vasati karmaṇah |

avandhya-kālo vaśyātmā sa vai paṇitita ucyate|| Prajaagara Parva 1.25 || [1]

Those having qualities of a wise leader always start any project with a well thought-out plan and once started, always acts until it is completed. Good leaders never waste their productive time and possess self-control.

\subsection{Honest Respectful towards merit}

ārya karmaṇi rajyante bhūti karmāṇi kurvate |

hitam ca nābhyasūyanti paṇ̣̂tā bharata-rșabha|| Prajaagara Parva 1.26 || [1]

This verse talks about a leader being pleased in doing noble deeds with honesty, engaged in tasks which will lead to happiness and prosperity and never involved in ridiculing or insulting anything or anyone good and has merit.

\subsection{Insight into human character Perceptive}

tattvajñah sarva bhūtānāìn yogajñah sarva karmaṇām |

upāyajño manuṣyānāàm narah pạ̣dita ucyate|| Prajaagara Parva 1.28 || [1] 
In this verse, Vidur ji talks about the wise quality of a leader to know the true character of everyone. Though spoken in spiritual sense here, it can also be inferred that a leader is one who has deep insight into human nature and behavior. A leader is considered wise if he/she is cognizant of the fact that things are inter-related, hence it can be said that he/she must be perceptive enough to be able to see the big picture behind the things. The verse also states that a leader must be well aware of the means people will resort to for attaining their objectives; this way he/she can be on guard for such means.

\title{
3.8. Articulate in speech: Knowledge of debating and Intellectual ability
}

pravritta vāk-citra katha ūhavān pratibhānavān |

āśu granthasya vaktā ca sa vai pạ̣dita ucyate|| Prajaagara Parva 1.29 || [1]

This verse talks about the literary and oratory qualities of a good leader. A good leader, as per this verse is one who is articulate in speech, can discuss on varied subjects, knows the science of argumentation i.e. can engage in debates successfully, is having intellectual ability and can interpret the hidden meaning of texts (which can be linked with the ability of reading between the lines, whether it's business proposals or interpersonal relationships).

\subsection{Learns from the wise}

\subsubsection{Balance of Virtue and Profit making ability}

prajñām evāgamayati yah prājũebhyah sa paṇditah $\mid$

prājño hyavāpya dharmārthau śaknoti sukham edhitum|| Prajaagara Parva 1.31 || [1]

In this verse, Mahatma Vidur says that a wise leader always endeavors to learn from the wise and is a learned person. He/she can wisely manage the balance between virtue (ethics) and profits i.e. he/she earns profits by virtue, ethically and therefore gains happiness.

\subsubsection{Humility}

arthai் mahāntam āsādya vidyām aiśvaryam eva vā | vicaraty-asamunnaddho yah sa paṇdita ucyate|| Prajaagara Parva 1.32 || [1]

In this verse, the essence of all qualities is mentioned. Here, Vidur ji says that even though a wise leader attain immense wealth, knowledge, power and prosperity with his/her actions, he/she never behave in an arrogant manner and is humble.

\subsection{Bad Leadership Attributes}

\subsubsection{Ignorant yet Haughty, Unrealistically high desires, and Use of unfair means to obtain wealth}

\author{
aśrutaśca samunnaddho daridraśca mahāmanāḥ | \\ arthāimścākarmaṇā prepsur mūạha ityucyate budhaih || Prajaagara Parva 1.33 || [1]
}

The qualities of bad leader, of course, are in contrast and in contradiction of the good attributes as stated in above verses. In this verse, Vidur ji says that a foolish leader would be one who though ignorant but is haughty, poor yet builds castles in the air and possess high unrealistic desires. Also, it is a bad attribute if he/she wishes to acquire wealth and riches without any effort by foul and unfair means. 


\title{
3.10.2. Interested in others' business instead of own: Dishonest with well-wishers
}

\author{
svam-artham yah parityajya parārtham anutișthati | \\ mithyā carati mitrārthe yaśca mū dhah sa ucyate || Prajaagara Parva 1.34 || [1]
}

A foolish leader would be one, as per this verse, who instead of paying attention to his/her own matters, is concerned with the business of others and acts treacherously with his/her friends. It means a foolish act would be one where a leader acts deceitfully with his/her well-wishers and treat them as foes.

\subsubsection{Considers foes as friends: Wicked}

amitram kurute mitram mitrai் dvești hinasti ca|

karma cārabhate dușțai் tam āhur mū ̣̦ha cetasam|| Prajaagara Parva 1.36 || [1]

In this verse, Mahatma Vidur says that a foolish person would be one who, on one hand, regards enemies as friends, trusts them, while, on the other hand contains malice and hatred for friends. It shows that a leader who is foolish would consider enemies as friends, would take their advices on matters whereas hating and disbelieving own friends. Also, a foolish leader would be involved in wicked and deplorable actions, such as, theft, embezzlement, or any other unlawful acts.

\subsubsection{Divulges projects, Skeptical, Spends long time in lesser time-taking activities}

\author{
samiārayati krtyāni sarvatra vicikitsate | \\ ciram karoti kṣiprārthe sa mūạho bharatarșabha || Prajaagara Parva 1.37 || [1]
}

This verse talks about considering a leader who divulges his/her projects to others, who is skeptical of each and everything and spends a lot of time in activities which should take up less time to be a fool. Here, it can be inferred that on one hand the leader is foolishly divulging the important details; while on the other hand, he/she is skeptical of whatever comes their way. The routine activities which ideally should take up less time - he/she spends maximum time being engaged in those.

\subsubsection{Goes uninvited, Over-talkative, and Trusting untrustworthy}

\author{
anāhūtaḥ praviśati aprṣ̦to bahu bhāṣate | \\ viśvasaty-apramatteșu mū ̣̣hacetā narādhamaḥ || Prajaagara Parva 1.38 || [1]
}

Here, in this verse, the qualities of the most foolish of all leaders are mentioned. A foolish leader would be one who goes to places uninvited, for example, barging in any ongoing discussion (formal/informal), visiting competitors' offices for no reason etc. The verse further states that a foolish leader would be the one who talks much without being asked, it may also implies that while delivering any training or lecture, he/she may go on and on without taking any break. Besides, a foolish leader would have habit of trusting those who cannot be trusted and are untrustworthy.

\subsubsection{Blaming others for own mistakes: Anger without authority}

param kṣipati doṣeṇa vartamānaḥ svayam tathā|

yaśca krudhyaty-anīśaḥ sansa ca mū ̣̣hatamo naraḥ|| Prajaagara Parva 1.39 || [1] 
A foolish leader is one who being himself/herself guilty always tries to caste the blame on others and who even though he/she does not held any power or authority over others, they vent anger on the subordinates or others.

\subsubsection{Directing the undeserving: Serves empty people}

aśișyam śāsti yo rājanyaśca śūnyam upāsate |

kadaryam bhajate yaśca tam āhur mūẹha cetasam|| Prajaagara Parva 1.41 || [1]

This verse conveys two meanings with the same two words, "aśisyam śāsti". This means a foolish leader is the one who instructs or directs those who are undeserving of any direction or advice. The alternate meaning is that the one who punishes those undeserving of punishment is a fool. The other characteristics of a foolish leader are serving incompetent people who are devoid of anything nice and placing trust in miserly persons.

\section{Conclusion}

This paper lists out the various attributes of a good leader and a bad leader in accordance with Vidur Neeti. A good and wise leader would demonstrate knowledge of self, is ethical in dealings, careful in actions, respectful, perseverant, wise, intellectual, a good orator, listener, honest and possesses deep insight into human nature to name a few. On the other hand, a foolish leader would exhibit characteristics as deception, dishonesty, arrogance, skepticism, wickedness, anger, etc. If proper attention to these minutest details of the personality of a leader is paid, an effective management and leadership could surely be reached.

\section{References}

[1] Achari RR. Vidura Niti. Vidūra Nīti - The Teachings of a Sudra Advisor. 2017.

[2] Shenoy R. Vidura Neeti and modern management. Published by ISOL Research Foundation; 2012.

[3] Khandelwal NM. A Managerial Analysis of Vidur Niti n.d.

[4] Mahajan V. Vidur niti ke vishesh sandarabh mein bharatiye neeti shastra ka adhyayana. 2006.

[5] Guruprasad, Rath J. Spiritual Traits that Affect the Leadership Performance-Reflection from Vidura Neeti. Int J Manag 2017;8:29-35.

[6] Ethical Values in 2009. http://ethicalvaluesinvidurniti.blogspot.com/2009/09/characteristics-of-wise-personsmarkof.html. 